\title{
INCIDENCE OF ALKALI RELEASE IN CONCRETE DAMS. EVALUATION OF ALKALIS RELEASABLE BY FELDSPARS
}

\author{
E. Menéndez ${ }^{1},{ }^{*}$, R. García-Rovés ${ }^{1}$, B. Aldea ${ }^{1}$ \\ ${ }^{1}$ Institute "Eduardo Torroja" of Construction Science (CSIC), Madrid, SPAIN
}

\begin{abstract}
Alkali release from aggregates can constitute a source of alkalis in concrete exposed to wet environments for long periods of time. Feldspars are one of the minerals that can release alkalis to the concrete with time. The formation of reaction products in the interface with the paste due to the alkali release from sodium and potassium feldspars has been observed in a concrete with granite aggregates. This has been observed after more than 25 years of exposure. It is necessary to evaluate the amount of alkalis releasable to define the formulation of concrete before manufacturing. Different test methods have been used to evaluate the potential alkali release from the granite extracted from the same quarry as that used in the dam. The test solutions have different composition and concentration, and different temperatures were used. Finally, the results of potential extraction are evaluated to determine the most realistic with respect to the field behavior.
\end{abstract}

\section{Introduction}

Different aggregates may give rise to the leaching of alkalis to the concrete. According to [1-6] the leaching of alkalis from feldspars has been confirmed. Likewise, $[4,6,7]$ indicate that the leaching of alkalis takes place in micas. According to $[4,6,8]$, there is only indirect evidence of the leaching of alkalis from the aggregates in the concrete to bring about an increase in the aggregate-alkali reaction in real concretes. However, according to $[9,10]$ there is direct evidence of damage caused by AAR in concrete, due to the leaching of alkalis from feldspars, associated with the presence of dawsonite and nepheline. Furthermore, [6] indicates that the sodium and potassium feldspars present in the alaskite may give rise to expansion and the formation of aggregate-alkali reaction products, concluding that feldspars may give rise to an increase in expansion in the concrete, especially when cements are used with a low content of alkalis, due to the incorporation of alkalis at the porous phase. Further, [11] observes that aggregates with potassium feldspars contribute to the formation of aggregate-silicate reaction products.

According to $[6,12]$ it is difficult to bring about decomposition of the feldspars in solutions of saturated $\mathrm{KOH}, \mathrm{NaOH}$ and $\mathrm{Ca}(\mathrm{OH})_{2}$. In these cases, the increase in alkalis in the solution or in the porous phase would be related to the ionic exchange of $\mathrm{Na}$ and $\mathrm{K}$ with $\mathrm{Ca}$. Furthermore, part of the leached alkalis is incorporated into the reaction products, even though the types of products formed depend on the composition of the solution and on the amount of $\mathrm{Ca}$ [12]. In accordance with the results, the $\mathrm{Na}$ of feldspars in alaskite is stable in alkaline solutions of $\mathrm{K}$ $(0.5 \mathrm{~N})$ and saturated $\mathrm{Ca}$. For its part, the $\mathrm{K}$ feldspars in this same solution give rise to a reduction in $\mathrm{Al}$ and $\mathrm{Si}$ and generate the formation of reaction products.

However, different authors are critical as regards the incidence of the alkalis leached from the aggregates in the development of the silica-alkali reaction. The alkalis liberated by the cement are produced under the conditions of an elevated presence of $\mathrm{CaO}$, which is why the $\mathrm{Na}^{+}$and the $\mathrm{K}^{+}$are not fixed $[6,12]$. Also, [13] indicate that in the case of potassium feldspar, $\mathrm{K}$ is liberated, but $\mathrm{Al}_{2} \mathrm{O}_{3}$ and $\mathrm{SiO}_{2}$ remain. These acid oxides need to be well combined with $\mathrm{CaO}$ or even with $\mathrm{K}_{2} \mathrm{O}$ and $\mathrm{Na}_{2} \mathrm{O}$ to give rise to high-basicity products. As regards the variations that are brought about in the solution of the porous phase of the concrete, $[14,15]$ indicate that the liberation of alkalis by the aggregates contributes to the increase in $\mathrm{OH}^{-}$ions and the $\mathrm{pH}$. However, the great contribution of alkalis to the porous phase is brought about by the contribution of the cement, even though this contribution of alkalis depends on the type of cement used.

Different test methods are used to evaluate the potential contribution of the alkalis of the aggregates to the concrete, with the aim of extracting and quantifying the alkalis of the aggregates. Van Aardt [16] analyses different tests proposed by [17-20]. These use different types of extraction solutions based on the use of solutions saturated in calcium [17-19], and calcium hydroxide solutions with an excess of

\footnotetext{
Correspondence to: emm@ietcc.csic.es
} 
calcium [20]. Furthermore [18] uses distilled water for the evaluation of the aggregates. For its part, [16] proposes a test method based on the use of solutions with both alkalis and calcium; using different methods for the test, such as distilled water, solution saturated with calcium hydroxide or with an excess, $0.7 \mathrm{~N}$ of $\mathrm{NaOH}$ and $0.7 \mathrm{~N}$ of $\mathrm{KOH}$. For its part, [6] uses an accelerated method, testing the aggregates at $150^{\circ} \mathrm{C}$ for 24 hours with saturated extraction solutions in calcium with excess, $0.7 \mathrm{~N}$ of $\mathrm{NaOH}$ saturated in calcium, and $0.7 \mathrm{~N} \mathrm{KOH}$ saturated in calcium. For its part, [21] uses solutions to simulate the $\mathrm{pH}$ of the porous phase of the concrete, with different proportions of sodium, potassium and calcium, testing granite aggregates for 28 days at $20^{\circ} \mathrm{C}$ and $40^{\circ} \mathrm{C}$. According to [22] the extraction of potassium and sodium with only $\mathrm{NaOH}$ or $\mathrm{KOH}$ is mainly due to ionic exchange processes and there is no change in the balance of ions in relation to the initial state. However, according to [23], when there is a total absence of calcium in the solution, the $\mathrm{OH}^{-}$ions are consumed and the $\mathrm{pH}$ drops and the anions of the aggregates are extracted, provided that there is no saturation of ions. However, in concrete, the portlandite may contribute $\mathrm{OH}^{-}$ions with the aim of re-establishing the balance with the cations in the porous solution. To avoid the drop in the $\mathrm{pH}$ and the consumption of $\mathrm{OH}^{-}$ions, it is necessary to use an excess of calcium hydroxide in the extraction solutions to supply these $\mathrm{OH}^{-}$ions $[16,24]$. For its part, [6] indicates that the maximum extraction of alkalis is brought about by saturated solutions with an excess of calcium. Menéndez [21] proves that saturated solutions in $\mathrm{Ca}(\mathrm{OH})_{2}$ and those that simulate the porous phase are the most efficient at $b$ extracting alkalis in granite-type aggregates. However, as well as extracting alkalis in the aggregates, it may give rise to the formation of aggregate-alkali reaction products in the aggregates subject to testing, especially in tests of a relatively long duration $[14,21]$. Furthermore, [6] indicates that the formation of reaction products may come about in the tests carried out with a low liquid:solid ratio, as there are not enough ions available in solution and a precipitation of the reaction products comes about.

According to [25] the different methods use different combinations of temperature, duration, type and concentration of extraction solutions, liquid/solid ratio, particle size and granulometry, sample size, agitation of sample and reposition of solution. But, very long tests are not useful to qualify the aggregates to be use in a short period of time. The most efficient methods to evaluate the alkali extraction from aggregates are those which use $\mathrm{Ca}(\mathrm{OH})_{2}$ saturated solutions, $80^{\circ} \mathrm{C}$ of temperature, 1:5 or 1:2 solid:liquid ratio, and a 28-day test period. Extractions of alkalis $\left(\mathrm{Na}_{2} \mathrm{O}_{\mathrm{e}}\right)$ to $5 \%$ have been found with these methods. These methods cannot be considered representative of the field concrete situation, but a more representative test of the field concrete needs a long period of test to qualify the aggregates.

In this work the contribution of alkali release from feldspars to the formation of alkali-silica reaction products is corroborated in a concrete dam. In addition, the potential extraction from the same granitic aggregates has been analyzed by different test methods, and comparison with the field behavior is done.

\section{Materials}

\subsection{Concrete from dam}

Some concrete samples were taken from the concrete affected by ASR and from areas without alteration. In the dam there is an area mainly affected by ASR, that it is located in the upper right side. All the samples are taken at least 3 meters deep from the central part of the structure to avoid carbonation. Samples of the concrete dam were analyzed to compare their composition with the composition of alkali feldspars before and after the alkaline extraction test.

\subsection{Granitic aggregates}

Granite, from the same quarry used in the dam concrete, analyzed to evaluate the potential extraction of alkalis and compare these results with the results of the extraction in the concrete.

\section{Characterization of aggregates from concrete and quarry}

\subsection{Aggregates from concrete dam}

The interior part of the largest coarse aggregates (diameter higher than $5 \mathrm{~cm}$ ) are considered as reference, because due to the low porosity of the granite aggregates, we consider that the pore solution has not penetrated more than 3 or 4 centimeters in depth. Alkali feldspar composition has been analyzed by EDX microanalysis. of interior zones of the aggregate and exterior zones close to the cement paste. The interior zones are considered as reference and the exterior zones are exposed to the pore solution. Also, samples taken from concrete affected by ASR and non-affected parts, have been analyzed. All the samples are taken at least 3 meters deep from the central part of the structure to avoid carbonation. The concrete is characterized by backscatter electron microscopy combined with X-ray dispersive spectroscopy, using Jeol 5400 equipment and an Oxford Link microanalysis In Figure 1 is shown the composition of the feldspars in the interior of aggregates.

In the microstructural analysis of the concretes, manufactured with this granite aggregate, the formation of reaction products, associated with the development of the silicate-alkali reaction is observed. These observations confirm the reactivity of these granite aggregates, including the feldspar phases. Formation of reaction products rich in sodium is 
observed close to the plagioclase, and products rich in potassium is observed close to the K-feldspars, this can be observed in Figure 2.

\subsection{Aggregates from quarry}

Different characteristics of the aggregates from the quarry have been analyzed.

Chemical composition: The chemical composition has determined by X-ray fluorescence (XRF), using Bruker S8 Tiger equipment, and the loss of ignition is determined through the difference in weight both before and after calcination at $1,000^{\circ} \mathrm{C}$. The average chemical composition of the aggregate is shown in Table 1 . The average alkali content is 4.33 to $4.53 \%$ in $\mathrm{K}_{2} \mathrm{O}$ and 2.91 to $2.55 \%$ in $\mathrm{Na}_{2} \mathrm{O}$, which corresponds to $3.2 \%$ of $\mathrm{Na}_{2} \mathrm{O}_{\text {e }}$.

Petrographic analysis: The petrographic analysis was done using an Olympus BX51 microscope. The petrographic classification was done according to ASTM C294 [29], with the granite classified as plutonic, oriented with plagioclase and potassium feldspars (granodiorite). The composition is detailed in Table 2. The plagioclases are greater than $3 \mathrm{~mm}$, they may be considered as reactive aggregates, favoring the reactivity of the alkaline phases which are altered to sericite and illite phases [30,31]. Petrologically, it is a calco-alkaline hercyniane granodiorite oriented at two micas $[32,33]$. The texture of the sodium and potassium feldspars, as well as that of quartz, can observed in Figure 3.

The reactivity index of the quartz, associated with its deformation, is estimated as the percentage of reactive quartz through image processing, according to the procedure of Menéndez et al [34,35]. If the reactivity index tends towards 1 , it is a more stable and ordered crystallographic network, though $1<\mathrm{I}_{\mathrm{Qr}_{\mathrm{r}}}<0.7$ indicate stable structures and without defects, and $0.7<\mathrm{I}_{\mathrm{Qr}}<0.4$ indicate structures with some defects, but stable. Moreover, if the index is close to 0 , it is a consequence of high deformation and reticular asymmetry, $\quad 0.4<\mathrm{I}_{\mathrm{Qr}}<0$ indicate deformed and fractured structures, developing phases with undulose extinction. A value very close to zero is mathematically impossible to obtain due to a purely geometrical problem and limits in reticular deformation. The quartz susceptible to reacting with alkalis is $82.5 \%$ of the total percentage of quartz of the sample, from Table 4 . The reactivity threshold $\mathrm{I}_{\mathrm{Qr}}$ is fixed at $\mathrm{I}_{\mathrm{Qr}}=0.26$, being less than 0.4 , and therefore, indicating a high reticular deformation of the quartz.

As a complementary petrographic analysis, the classification of the aggregate was also carried out according to the test method recommended in RILEM AAR-1 [36]. RILEM AAR-1 classifies the aggregate in type III-S (very probable reactivity with alkalis), since it contains quartz with a high reticular deformation, sarcoid quartz, altered feldspars, altered micas and occasional opaque materials, as potentially reactive mineralogical phases.
Microstructural characterization: The aggregate is characterized by backscattering electron microscopy combined with EDS, using Jeol 5400 equipment and an Oxford Link microanalysis. It is corroborated the similar composition of the phases in the quarry aggregates with respect to the aggregates of the concrete samples analyzed.

Expansion according to the ASTM C1260 and ASTM C227: The potential expansion of the granite aggregates, analyzing the fine grading fraction below $5 \mathrm{~mm}$, by means of accelerated and semi-accelerated tests, was determined. The potential expansion of the aggregate was done according the accelerated mortar bar test, ASTM C1260 standard [37] (Figure 4a), and with semi-accelerated mortar bar test ASTM C227 standard [38] (Figure 4b). The aggregate is qualified as potentially reactive, both in the accelerated and in the semi-accelerated test, even though it is at the limit of reactivity, especially in the accelerated test. These results indicate that the aggregate is potentially reactive with the alkalis, with slow reactivity. Usually concretes manufactured with these aggregates need time to manifest the expansion, depending on environmental conditions of exposition.

\section{Potential extraction of alkalis from aggregates}

\subsection{Method of extraction}

There are different test methods that use different parameters of test: size of aggregates, liquid:solid ratio, temperature, time and extraction solutions, to evaluate the potential leaching of alkalis from the aggregates [25]. The different conditions of test have a significant influence on the results of potential extraction. These tests are based on subjecting the aggregates to the action of the solutions with a high $\mathrm{pH}$, similar to the porous phase of the concrete. Furthermore, the extraction of the ultrapure water is analyzed, as a reference for neutral $\mathrm{pH}$.

Six tests have been used to analyze the behavior of the aggregates under different test conditions and to evaluate which of them are the most efficient. Method 1 is carried out with distilled water in ultrapure water for 48 hours, which means a moderate test time, even though the average test has a $\mathrm{pH}$ different from that of the porous phase of the concrete [21,39]. Method 2 is based on the use of solutions with an elevated $\mathrm{pH}$, similar to the values of the liquid phase of the concrete, with a different combination of ions but with an exposure time of 28 days [21,39]. Method 3 also used solutions with an elevated $\mathrm{pH}$, but it has some conditions very far from the conditions of the concrete at $150^{\circ} \mathrm{C}$ for 24 hours [40]. Method 4 is a method used to determine the soluble alkali content of concrete [41]. Method 5 is an alternative method to determine the content of soluble alkali cements [35]. Method 6 is a method currently under study to determine the leaching of alkali aggregate in concrete [42].The test conditions used are detailed in Table 4. 


\subsection{Results of extraction from aggregates}

The ions leached at the end of each test are analyzed, determining the concentration by inductive plasma spectroscopy (ICP), using Varian 725-ES equipment. Also, the $\mathrm{pH}$ value of solutions is measured at the beginning and the end. The concentration of alkalioxides present in the solution is calculated and the equivalent sodium oxide is determined, according with the following equation: $\mathrm{Na}_{2} \mathrm{O}_{e}=\mathrm{Na}_{2} \mathrm{O}+$ $0.658 \cdot \mathrm{K}_{2} \mathrm{O}$.

The percentages of $\mathrm{Na}_{2} \mathrm{O}$ and $\mathrm{K}_{2} \mathrm{O}$ leached from the aggregates by mass of the aggregate and the $\mathrm{Na}_{2} \mathrm{O}_{e}$ are detailed in Figure 5. It is seen that, in general, a moderate extraction of alkalis from the aggregates takes place, which varies in accordance with the type of extraction solution used. The saturated solutions in calcium hydroxide are the most efficient (D3 and R1) and the D6 solution, which simulates the concentration of alkalis present in the aqueous phase of the concrete [40]. In the case of the solutions only with calcium, the extraction can be attributed to the $\mathrm{Na}-\mathrm{Ca}$ or K-Ca ionic exchange; however, the behavior observed in the solution with the three ions (D6) indicates that the potential migration of alkalis to the concrete is feasible. On the other hand, in some cases a decrease in the sodium ion or the potassium ion of the solution is observed. The combination of the sodium ion in the aggregates is produced in the D1 solution in which there is an elevated concentration of sodium $(1 \mathrm{~N}$ of $\mathrm{NaOH})$, therefore this behavior is associated with the $\mathrm{Na}-\mathrm{K}$ ionic exchange, giving rise to the substitution of potassium in the aggregates for sodium. For its part, a similar behavior is observed in the solutions with an elevated content of potassium (D2 and D6), which contain respectively $1 \mathrm{~N}$ of $\mathrm{KOH}$ and $0.5 \mathrm{~N}$ of $\mathrm{KOH}$; in this case the ionic exchange would be K-Na, which would give rise to a potassium ion defect in the solution. As regards the ultrapure water and the R1 to R5, it is observed that the extraction is more moderate than in the D1 to D6 test solutions, which indicates that the most determinant factor for the extraction of the alkalis is time, much more than temperature, since in alkali solutions at $150^{\circ} \mathrm{C}$ ( $\mathrm{R} 1$ to $\mathrm{R} 5$ ) the extraction is less than for solutions with similar $\mathrm{pH}$ tested at $20^{\circ} \mathrm{C}$ and $40^{\circ} \mathrm{C}$. The time factor is also corroborated as the determinant for the results obtained in the solutions D1 to D6, exposed at $20^{\circ} \mathrm{C}$ and $40^{\circ} \mathrm{C}$, observing that the extraction is of the same order or in some cases higher, in the tests at $20^{\circ} \mathrm{C}$. Figure 5 shows the results of the extraction of $\mathrm{Na}_{2} \mathrm{O}$ and $\mathrm{K}_{2} \mathrm{O}$ in the same tests.

The results of the equivalent sodium oxide show similar results to the extraction of each ion. It is observed that the most effective solutions in the extraction are saturated in calcium, and the one that simulates the $\mathrm{pH}$ and the chemical composition of the liquid phase network of the concrete. Likewise, it is observed that the time in contact with the extraction solution is more important than the exposure temperature, even when solutions are used at $150^{\circ} \mathrm{C}$. On the other hand, the solutions only with sodium or potassium, without calcium, are not efficient in the extraction of the alkalis of the feldspars in spite of having a $\mathrm{pH}$ similar to that of the liquid phase, which indicates the significant role of the calcium in this process. The action of the calcium will be related to the Na-Ca or K-Ca ionic exchange, even though this situation will come about in the same way in the concrete, since the portlandite is dissolved to maintain the elevated $\mathrm{pH}$ of the liquid phase and makes enough calcium available for this exchange. Figure 5 shows the results of the equivalent sodium oxides extracted in each test solution.

The variation in the $\mathrm{pH}$ between the beginning and the end of the test shows that in all of the alkaline solutions, the $\mathrm{pH}$ declines, as a consequence of the increase in ions in solution and the attack of the $\mathrm{OH}^{-}$ ions on the aggregates. In the ultrapure water there is an increase in $\mathrm{pH}$, because of the extraction of alkalis and other ions from the aggregates, which gives rise to an increase in $\mathrm{OH}^{-}$ions to maintain the equilibrium of charges (Figure 6).

The potential supply of alkalis to the concrete can be calculated from the results obtained from the extraction tests. If we assume a standard proportion of concrete with $1800 \mathrm{~kg} / \mathrm{m}^{3}$ of aggregates $\left(1.000 \mathrm{~kg} / \mathrm{m}^{3}\right.$ of coarse aggregates), we have a potential maximum extraction from this granitic aggregate (expressed as $\left.\mathrm{Na}_{2} \mathrm{O}_{\mathrm{e}}\right)$ of $2.53 \mathrm{~kg} / \mathrm{m}^{3}\left(\mathrm{Ca}(\mathrm{OH})_{2}\right.$ sat. $\left.-20^{\circ} \mathrm{C}-28 \mathrm{~d}\right), 1.98$ $\mathrm{kg} / \mathrm{m}^{3}\left(\mathrm{Ca}(\mathrm{OH})_{2}\right.$ sat. $\left.-40^{\circ} \mathrm{C}-28 \mathrm{~d}\right)$ and $0.77 \mathrm{~kg} / \mathrm{m}^{3}$ $\left(\mathrm{Ca}(\mathrm{OH})_{2}\right.$ sat. $\left.-150^{\circ} \mathrm{C}-24 \mathrm{~h}\right)$. But when $\mathrm{K}^{+}$and $\mathrm{Na}^{+}$ with $0,7 \mathrm{M} \quad \mathrm{NaOH}+\mathrm{Ca}(\mathrm{OH})_{2}$ sat. and $0,7 \mathrm{M}$ $\mathrm{KOH}+\mathrm{Ca}(\mathrm{OH})_{2}$ sat. respectively are quantified, we obtained values of $5.09 \mathrm{~kg} / \mathrm{m}^{3}$ and $6.12 \mathrm{~kg} / \mathrm{m}^{3}$ of $\mathrm{Na}_{2} \mathrm{Oe}$ at $38^{\circ} \mathrm{C}$ or $60^{\circ} \mathrm{C}$. In accordance with these values, the increase in alkalis in the concrete may have a significant influence on the development of the silicate-alkali reaction, if we consider that $400 \mathrm{~kg} / \mathrm{m}^{3}$ of cement supplies between 2.4 and $3.2 \mathrm{~kg} / \mathrm{m}^{3}$ of alkalis, for a $\mathrm{Na}_{2} \mathrm{O}_{e}$ content of $0.6 \%$ (low alkali cements) or $0,8 \%$. However, the efficiency of the extraction in the concrete must be taken into account, since not all of the surface of the aggregate is in contact with the liquid phase and has the potentiality of leaching alkalis.

\section{Conclusions}

It has been proven that granite aggregates with alkaline feldspars may leach alkalis in contact with solutions with an elevated $\mathrm{pH}$, as happens in concrete. This extraction increases the risk of a alkali-silica reaction taking place, observing the formation of reaction products in the interfaces of the feldspars with the cement paste.

Different test conditions are analyzed for the extraction of alkalis, with different extraction solution compositions, test temperature and contact time. It is concluded that the determining parameter for the extraction is the duration of the test, thus the tests at 28 days at $20^{\circ} \mathrm{C}$ or $40^{\circ} \mathrm{C}$ extract more alkalis than those carried out at $150^{\circ} \mathrm{C}$ for 24 hours. For its part, the most 
efficient extraction solutions are those saturated in calcium hydroxide and which simulate the composition of the liquid phase of the concrete (with sodium, potassium and saturated calcium), which corroborates the potential of the extraction of alkalis of the feldspars in the concrete. The role of the calcium is related to the ionic exchange with the sodium and potassium, which could be brought about in the concrete, given the elevated content of calcium in its liquid phase.

In accordance with the different extraction test methods used, the granite aggregates could contribute between 0.77 and $6.12 \mathrm{~kg} / \mathrm{m}^{3}$ of alkalis to the concrete, which would notably increase the risk of a silicatealkali reaction. Even though the efficiency of the extraction has to be taken into account, not all of the surface of the aggregates is in contact with the aqueous phase of the concrete.

\section{REFERENCES}

[1] Van Aardt, J.H.P., Visser, S. (1997): Formation of hydrogarnets: Calcium hydroxide attack on clays and feldspars. Cement and Concrete Research. (7): 39-44

[2] Constantiner D, Diamond S (2003): Alkali release from feldspars into pore solutions. Cem. and Conc. Res, 33(4): 549-554

[3] Bérubé, M.A, Dorion, J.F., Rivest, M, (2000): Distribution of alkalis in concrete structures affected by ASR, contribution by aggregates A. In: Proc. $11^{\text {th }}$ ICAAR Conference Proceedings: Québec City, Canada: 139-148

[4] Bérubé, MA, Dorion J.F., Rivest M (2002): Laboratory assessment of alkali contribution by aggregates to concrete and application to concrete structures affected by ASR. Conference Proceedings 32(8):1215-1227

[5] Wang, Y, Mo, L, Deng, M, Tang, M (2004): Thermodynamic analysis on decomposition of feldspar mineral under alkali condition. $12^{\text {th }}$ ICAAR Conference Proceedings, Beijing, China: 211-220

[6] Wang, H. y Gilliot, J.E. (1991), Mechanisms of alkali-silica reaction and the significate of calcium hydroxide. Cement \& Concrete Research, 21(4): pp 647-654

[7] Wang, Y., Deng M., Tang, M. (2008): Alkali release from aggregate and the effect on AAR expansion. Materials and Structures. (41):159-171

[8] Grattan-Bellew P.E., Beaudouin J.J. (1980): Effect of phlogopite mica on alkali-aggregate expansion in concrete. Cement and Concrete Research 10(6):789-797

[9] Shayan, A, (2004): Alkali-aggregate reaction and basalt aggregate. $12^{\text {th }}$ ICAAR, Beijing, China: $1130-1135$

[10] Gillott, J.E., Rogers C.A. (1994): Alkaliaggregate reaction and internal release of alkalis. Mag. Concrete Research. 46(167):99-112
[11] Durand, B. (2000): A note about alkali contribution from aggregates in concrete affected by ASR. $11^{\text {th }}$ ICAAR, Québec City, Canada: 169177

[12] Bérubé, M.A., Duchesnea, J., Doriona, J.F., Rivest, M. (2004): A reply to the discussion by Mingshu Tang of the paper "Laboratory assessment of alkali contribution by aggregates to concrete and application to concrete structures affected by alkali-silica reactivity', Cement and Concrete Research (34):903-904

[13] Mingshu, T (2004): A discussion of paper "Laboratory assessment of alkali contribution by aggregates to concrete and application to concrete structures affected by alkali-silica reactivity by M.-A. Berube, J. Duchesne, J.F. Dorion and M. Rivest. Cement and Concrete Research (34):901

[14] Constantiner, D., Diamond, S. (2003): Alkali release from feldspars into pore solutions. Cem. and Conc. Res. (33):549- 554

[15] Bérubé, M.A., Duchesnea, J. Doriona, J.F. Rivest, M. (2002): Laboratory assessment of alkali contribution by aggregates to concrete and application to concrete structures affected by alkali-silica reactivity. Cement and Concrete Research 32: 1215-1227

[16] Van Aardt JHP, Visser S (1977): Calcium hydroxide attack on feldspars and clays: possible relevance to cement-aggregate reactions. Cement and Concrete Research. 7(6): 643-648

[17] D. Stark, M.S. Bhatty, Alkali- silica reactivity: Effect of alkali in aggregate on expansion, Alkalis in Concrete, ASTM Spec. Tech. Publ., vol. 930, 1986, pp. 16-30.

[18] M. Kawamura, M. Koike, K. Nakano, Release of alkalies from reactive andesitic aggregates and fly ashes into pore solution in mortars, in: K. Okada, S. Nishibayashi, M. Kawamura (Eds.), Proceedings of the $8^{\text {th }}$ International Conference on AAR, Society of Materials Science, Kyoto, 1989, pp. 271-278.

[19] LCPC (Laboratoire Central des Ponts et Chausse'es), Essai de granulat — de'termination des alcalins solubles dans l'eau de chaux, Me'thode d'essai no. 37, Paris, 1993.

[20] W. Yujiang, D. Min, T. Mingshu, (2008) Alkali release from aggregate and the effect on AAR Expansion, Materials and Structures 41:159171

[21] E. Menéndez, N. Prendes, A. Gil, A.B. Marín, (2011) Evaluation of the potential alkalisilica reaction development of Spanish granitic rocks by lixiviation test. Workshop Predicting AAR: Developing a Practical \& Reliable Performance Test. RILEM TC on AlkaliAggregate Reactions in Concrte Structures, May, 2011 Reyjavik (Iceland)

[22] C. Shi, (2004) A discussion of the paper " 'Laboratory assessment of alkali contribution by aggregates to concrete and application to concrete structures affected by alkali-silica reactivity" by 
M. -A. Berube, J. Duchesen, J. F. Dorion and M. Rivest, Cement and Concrete Research 34:895

[23] M.A. Berubé, J. Duchesne, J.F. Dorion, M. Rivest, (2004), Reply to the discussion by C. Shi of the paper "Laboratory assessment of alkali contribution by aggregates to concrete and application to concrete structures affected by alkali-silica reactivity', Cement and Concrete Research 34: 897-899

[24] D. Stark, Alkali-aggregate reactivity in the Rocky Mountain region, in: S. Diamond (Ed.), Proceedings of the 4th International Conference on AAR, Purdue, 1978, pp. 235- 244 (Publ. No. CEMAT-1-78)

[25] Menéndez, E., García-Roves, R., Ruiz, S. 2016, Alkali release from aggregates: contribution on ASR, Construction Materials, Volume 169, Issue CM4, pp. 206-214

[26] Gil, A., Cajete, J. (1991): Study on The Interaction Aggregate-paste in the Concrete at the San Esteban Dam. Dix-septième Congres des Grands Barrages. Vienne, Commission Internationale des Grands Barrages: 65-88

[27] Cajete, J., Delgado, C. (1989) : Regeneración e impermeabilización del hormigón de la Presa de San Esteban, Orense (España). Conferencia sobre Potenciación y Remodelación de Plantas Hidroeléctricas. Zurich: 7-15

[28] Menéndez, E., Prendes, N., Márquez, C., Aldea, B. (2011), Analysis of the concrete of San Esteban dam. HOREX Project. Inform 19.346-F6

[29] Standard Descriptive Nomenclature for Constituents of natural Mineral Agrgregates (1986). ASTM C 294-86. pp. 167-173

[30] Reacción Álcali-Árido en Presas de Hormigón. (1994). Ideas Generales y Recomendaciones. Monografías 17. Colegio de Ingenieros de Caminos, Canales y Puertos. Comité Español de Grandes Presas. pp. 112

[31] Mather, C. (1966). Petrographic examination. Hardened Concrete. Symposium on Significance of Properties of Concrete and Concrete Making Materials. pp. 125-143

[32] Mapa Geológico de España E. 1:50.000 y Memoria explicativa. Hoja Nogueira de Ramuin. (1974) Segunda serie. $1^{\mathrm{a}}$ Ed. IGME. D.L. 5.6121974. pp 37
[33] Salinas, J. L. (1983). Recomendaciones para una normalización del Estudio Petrológiuco de los Áridos. Documentos del laboratorio de Carreteras Vicente Escario. pp 105-124

[34] Menéndez, E., García-Rovés, R., Aldea, B., Ruíz, S., 2016c, Alkali release of aggregates. Effectiveness of different solutions and conditions of test, Proceedings of the 13th ICAAR. Eds., Sao Paulo, Brasil

[35] Menéndez, E., García-Rovés, R., Prendes, N., 2015b, Metodología avanzada de evaluación petrográfica de áridos para predecir su potencial reactividad frente a los álcalis del hormigón, Proceedings del IV Congreso Nacional de Áridos, Madrid 2015

[36] RILEM Recommended Test Method AAR-1: Detection of potential alkali-reactivity of aggregates - Petrographic method, Materials and Structures, Vol. 36, August-September 2003, pp480-496

[37] ASTM C1260 (2007). Standard Test Method for Potential Alkali Reactivity of Aggregates (Mortar-Bar Method)

[38] ASTM C227 (2003). Standard Test Method for Potential Alkali Reactivity of Cement Aggregate Combinations (Mortar Bar Method)

[39] E. Menéndez, N. Prendes, C. Márquez, B. Aldea, (2012), Evaluation of Granitic Aggregates Behavior in Relation with the Alkaline Extraction and Compositional Change in their Phases, In Proceedings of the 12th International Conference on Alkali-Aggregate Reactivity in Concrete, Drimalas, T., Ideker J.H. and Fournier, B. Eds., Austin, Texas, USA, 2012, 10 pp.

[40] Longet, P. Longuet, L Burglen, Zelwer, A. (1973): The Liquid Phase of Hydrated Cement. Mat. Const. 676:35-41

[41] Bérubé, M.A., Frenette, J., Rivest, M., Vezina, D. (2002). Measurement of the alkali content of concrete using hot-water extraction. Cement, concrete and Aggregates, CCAGDP, Vol. 24, No 1 , pp 28-36.

[42] Menéndez, E., Fournier, B., Santos, A., Justnes, H. Draft AAR-8: Determination of Alkalis Releasable by Aggregates in Concrete. (2015). RILEM TC 219-ACS

TABLE 1. Average chemical composition of the granite aggregate.

\begin{tabular}{|c|c|c|c|c|c|c|c|c|c|c|c|c|c|c|c|}
\hline Comp. & LOI & $\mathrm{SiO}_{2}$ & $\mathrm{Al}_{2} \mathrm{O}_{3}$ & $\mathrm{Fe}_{2} \mathrm{O}_{3}$ & $\mathrm{CaO}$ & $\mathrm{MgO}$ & $\mathrm{P}_{2} \mathrm{O}_{5}$ & $\mathrm{SO}_{3}$ & $\mathrm{TiO}_{2}$ & $\mathrm{Rb}_{2} \mathrm{O}$ & $\mathrm{Cr}_{2} \mathrm{O}_{3}$ & $\mathrm{MnO}$ & $\mathrm{K}_{2} \mathrm{O}$ & $\mathrm{Na} 2 \mathrm{O}$ & $\mathrm{Na}_{2} \mathrm{O}_{\mathrm{eq}}$ \\
\hline$(\%)$ & 0.78 & 58.85 & 12.36 & 1.12 & 0.66 & 0.27 & 0.43 & 0.08 & 0.18 & 0.04 & 0.02 & 0.01 & 4.45 & 2.84 & 5.77 \\
\hline
\end{tabular}

TABLE 2. Petrographic characterization of the granite aggregate.

\begin{tabular}{|c|c|c|c|}
\hline Minerals & Phases & Range (\%) & Characteristics of the phases \\
\hline \multirow{4}{*}{ Essentials } & Feldspar Na & $34.5 \%$ & Partially altered rings \\
\cline { 2 - 4 } & Feldspar K & $23.2 \%$ & Altered clays (Chlorites, etc.) \\
\cline { 2 - 4 } & Quartz & $19.5 \%$ & Undulose extinction $(>26 \%)$ \\
\cline { 2 - 4 } & Micas (Biotite) & $15.3 \%$ & Pleochroism with wafer texture \\
\cline { 2 - 4 } & Muscovite & $4 \%$ & Foiled structure. Green, partially altered \\
\hline \multirow{2}{*}{ Accessories } & Chlorites & $2.7 \%$ & High interference colours \\
\cline { 2 - 4 } & Opaques & $0.8 \%$ & Sulphite phases \\
\hline
\end{tabular}


TABLE 3: Analysis of the reactivity of the quartz.

\begin{tabular}{|c|c|c|c|c|}
\hline Q total & Q React & $\mathbf{\% Q}_{\text {reactive }}$ of the $\% \mathbf{Q}_{\text {total }}$ & $\mathbf{I}_{\mathbf{Q r}}$ (adimensional) & Reticular state of the Q \\
\hline $19.5 \%$ & $16.1 \%$ & 82.5 & $\sim 0.26$ & Microgranular crystals, fissured and sarcoid sandstone \\
\hline
\end{tabular}

TABLE 4. Test conditions of the different test methods for the extraction of alkalis.

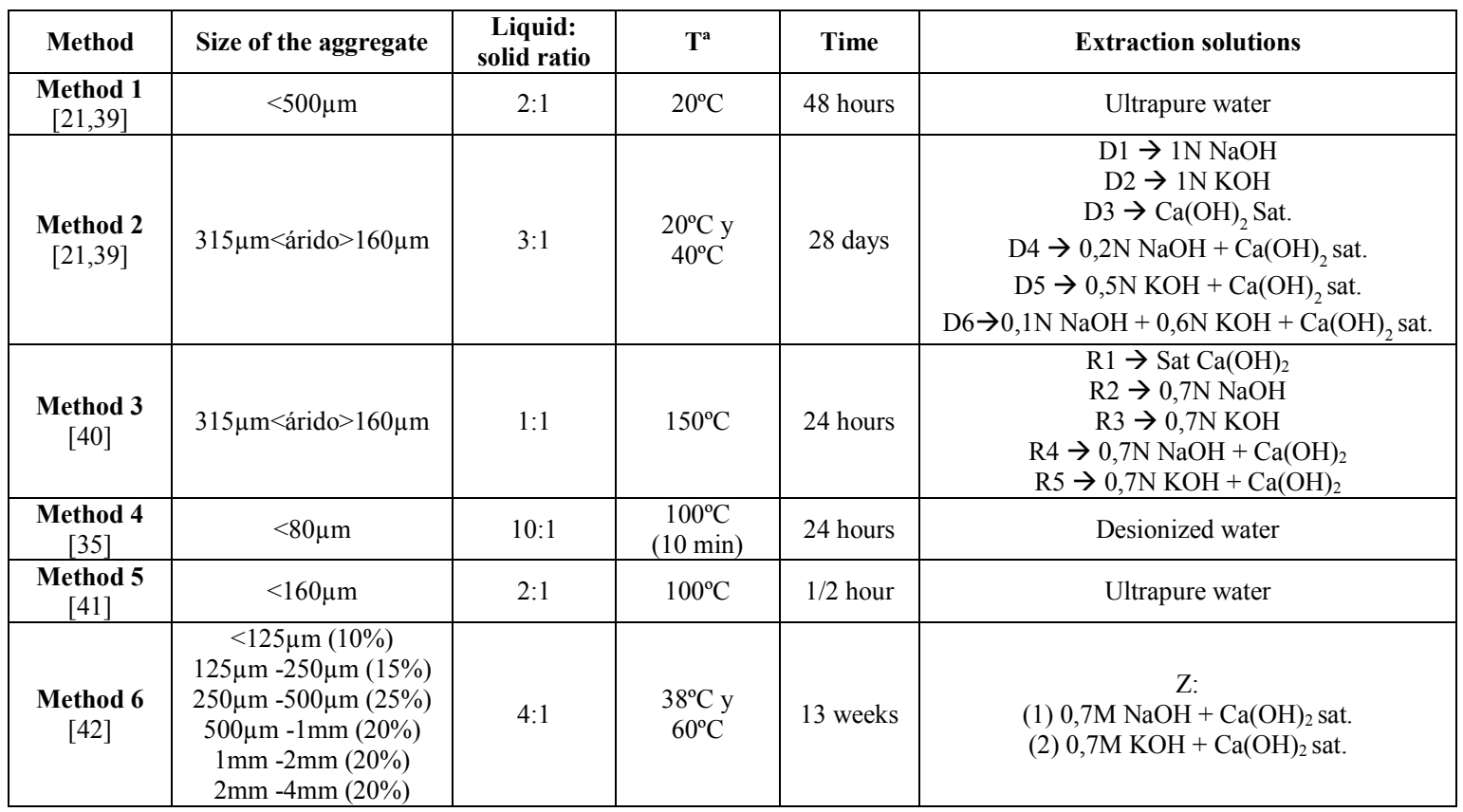

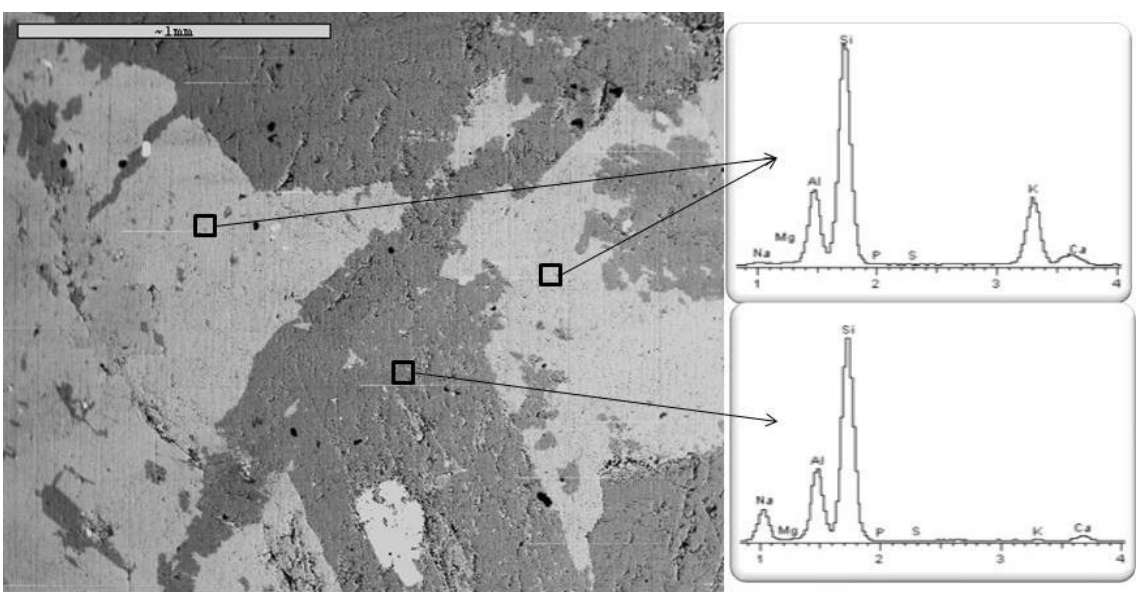

FIGURE 1: Microstructural and microanalytical aspect of alkaline feldspar. 


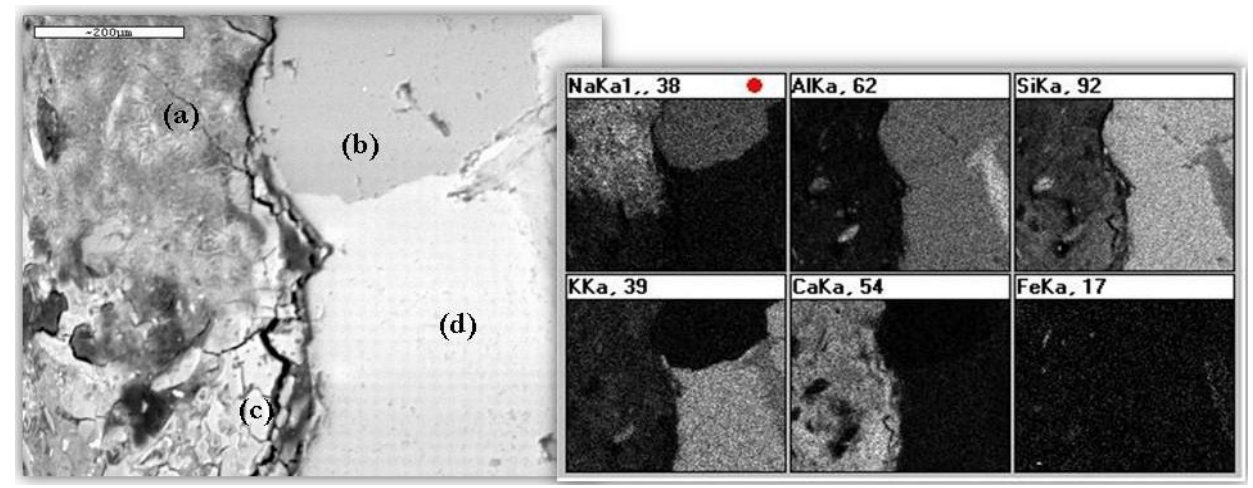

FIGURE 2: Paste-aggregate interface with ASR products, microcrystals (a) and gel (c), close to Na-feldspar (b) and K-feldspar (d).
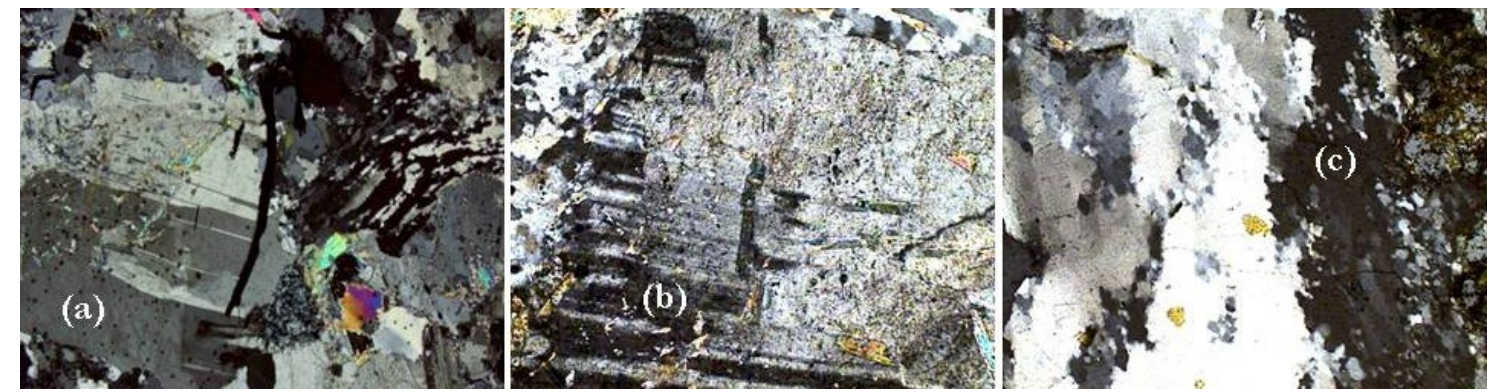

FIGURE 3: Granodiorite petrography analysis, (a) Na feldspars (plagioclase), (b) K feldspars and (c) sarcoid quartz.
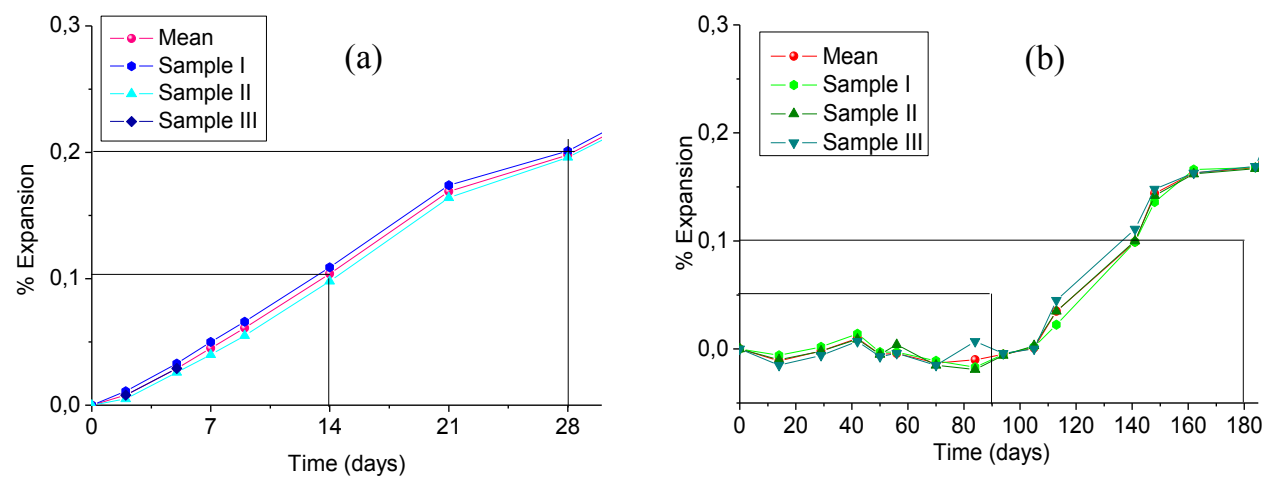

FIGURE 4. Potential expansion of the granite aggregates by means of the accelerated method of mortar bars (a) and by means of the semi-accelerated method of expansion (b). 


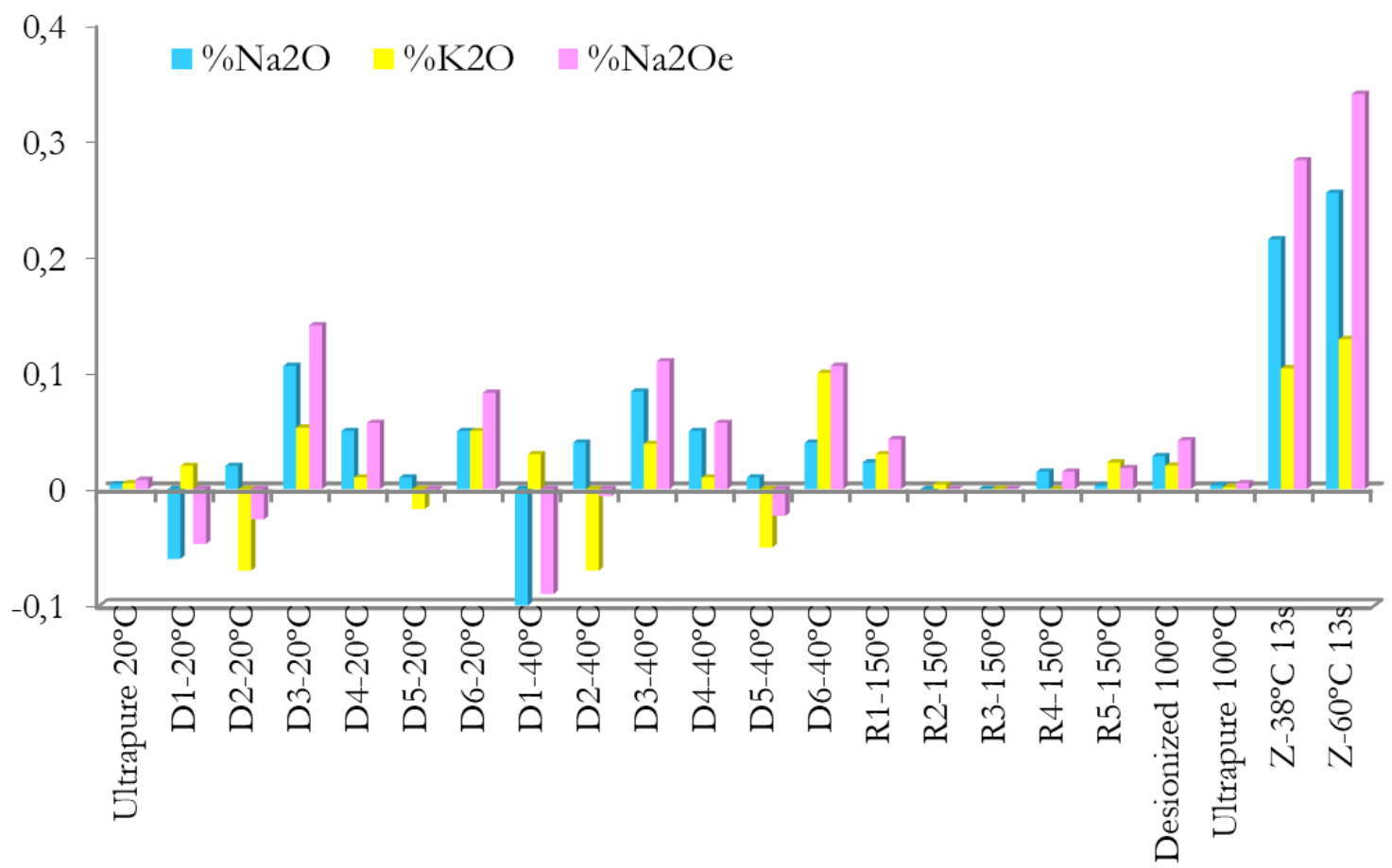

FIGURE 5. Alkalis extracted from the different test solutions, expressed as $\mathrm{Na}_{2} \mathrm{O}, \mathrm{K}_{2} \mathrm{O}$ y $\mathrm{Na}_{2} \mathrm{O}_{\text {e. }}$.

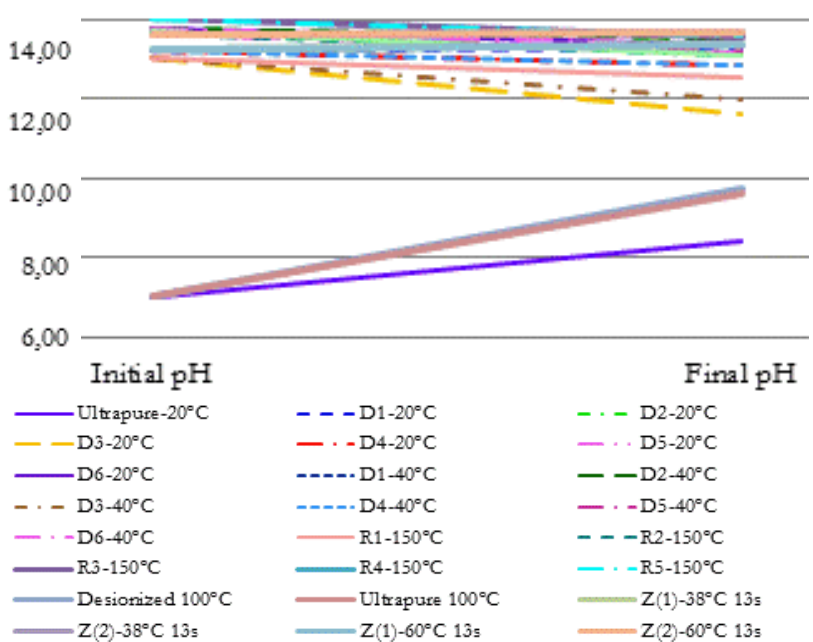

FIGURE 6. Variation in $\mathrm{pH}$ in the solutions at the beginning and the end of the test. 